\title{
Neuroprotection Offered by Majun Khadar, a Traditional Unani Medicine, during Cerebral Ischemic Damage in Rats
}

\author{
Seema Yousuf, ${ }^{1}$ Fahim Atif, ${ }^{1,2}$ Muzamil Ahmad, ${ }^{1}$ Tauheed Ishrat, ${ }^{1}$ Badruzzaman Khan, ${ }^{1}$ \\ and Fakhrul Islam ${ }^{1}$ \\ ${ }^{1}$ Neurotoxicology Laboratory, Department of Medical Elementology and Toxicology, \\ Jamia Hamdard (Hamdard University), New Delhi 110062, India \\ ${ }^{2}$ Brain Research Laboratory, Department of Emergency Medicine, Emory University, Atlanta, Georgia 30322, USA
}

Correspondence should be addressed to Fakhrul Islam, fislam2008@yahoo.co.in

Received 17 May 2009; Accepted 1 December 2009

Copyright () 2011 Seema Yousuf et al. This is an open access article distributed under the Creative Commons Attribution License, which permits unrestricted use, distribution, and reproduction in any medium, provided the original work is properly cited.

\begin{abstract}
Stroke results in damages to many biochemical, molecular and behavioral deficits. Present study provides evidence of the protective efficacy of a Unani herbal medicine, Majun Khadar (MK), against cerebral ischemia-induced behavioral dysfunctions and neurochemical alterations in the hippocampus (HIP). Transient focal cerebral ischemia was induced for $2 \mathrm{~h}$ followed by reperfusion for $22 \mathrm{~h}$ in a rat model. Rats were divided into four groups: sham, middle cerebral artery occluded (MCAO), drug sham (MK; $0.816 \mathrm{~g} \mathrm{~kg}^{-1}$ orally for 15 days) and MK pre-treated ischemic group (MK + MCAO). Levels of enzymatic and non-enzymatic antioxidants were estimated in HIP along with behavioral testing. MK pre-treatment significantly $(P<.05-.001)$ restored the activities of glutathione peroxidase $(\mathrm{GP} \times)$, glutathione reductase (GR), glutathione S-transferase (GST) and decreased the level of lipid peroxidation (LPO) and $\mathrm{H}_{2} \mathrm{O}_{2}$ content in HIP in the MK + MCAO group which were severely altered in the MCAO group. The content of glutathione (GSH), total thiols (TT) and ascorbic acid (AsA) was significantly depleted in the MCAO group; pretreatment with MK was able to restore its levels. Also in the MK + MCAO group, significant $(P<.5-.001)$ recovery in behavioral testing by rota rod and open-field activities was seen as compared with the MCAO group. MK alone did not show any change neither in the status of various antioxidants nor behavioral functions over sham values. Although detailed studies are required for the evaluation of exact neuroprotective mechanism of MK against cerebral ischemia these preliminary experimental findings conclude that MK exhibits neuroprotective effect in cerebral ischemia by potentiating the antioxidant defense system of the brain.
\end{abstract}

\section{Introduction}

A $100 \%$ prophylaxis over cerebral ischemia-induced neuronal death which initiates intracellular acidosis, increased concentrations of intracellular calcium and overproduction of reactive oxygen species is still a long way to come. Ischemic damage is severe in those regions where cerebral blood flow is restored because reflow to previous ischemic brain regions results in an increase in the oxygen level; therefore, severe oxidative injury occurs [1]. The penumbral region of the ischemic territory has the potential to be salvaged by timely drug intervention.

Growing attention is being paid to traditional medicines, as they have been proved therapeutically/prophylactically fruitful against manifold diseases, which can be evaluated by the dependence of 3.2 billion people $(64 \%)$ of the whole world population on traditional medicines [2]. Many workers reported the beneficial effects of traditional medicines against brain ischemia. Yousuf et al. [3, 4], while evaluating the effect of Khamira Abresham, Majun Baladar against cerebral ischemia-induced oxidative damage in discrete brain part, report a protective role of these Unani formulations by the synergistic modulation of its various antioxidant compounds. Numerous single compounds have also shown their importance, for example, Saffron and herbal extract of Nardostachys jatamansi were also found to be protective against cerebral ischemic oxidative damage $[5,6]$. Ahmad et al. [7] reported the neuroprotection offered by sesame oil on brain hippocampus after focal cerebral ischemic damage.

The promising results of Khamira Abresham and Majun Baladar prompted us to evaluate the neuroprotective efficacy of another Unani herbal formulation, Majun Khadar (MK), 
against cerebral ischemic damage. MK has 27 constituents, with different therapeutic values and has firm grounds of pharmacological efficacy in disorders ranging from heart, nerve, gastrointestinal disorders, and so forth $[8,9]$. These constituents of MK individually are potent free radical scavengers (Figure 1) (saffron, borage, mint, cinnamon, Nardostachys jatamansi); anti-inflammatory and brain boosting agents (cinnamon, honey, chebulic, myrobalan, mint); and vasodilators/nerve relaxants (cardamom, usnea, saffron) (see Table 1 for references). Since the oxidative stress and inflammation play a key role in ischemic neuronal death, we evaluated the synergistic efficacy of these different constituents by testing MK against cerebral ischemia-induced oxidative damage in rat brain and associated behavioral dysfunctions.

\section{Methods}

2.1. Drugs and Chemicals. Glutathione (oxidized and reduced), nicotinamide adenine dinucleotide phosphatereduced form (NADPH), Oubain, Phenol Red, Horseradish peroxide (Hrp), 1-chloro-2,4-dinitrobenzene (CDNB), 5, 5' dithiobis-2-nitrobenzoic acid (DTNB) and thiobarbituric acid (TBA) were purchased from Sigma-Aldrich (St. Louis, MO, USA). Other chemicals were of analytical reagent grade. Majun Khadar (MK) was procured from Hamdard (Waqf) Laboratories (Ghaziabad, Uttar Pradesh, India).

2.2. Animals. Male Wistar rats, weighing $300-350 \mathrm{~g}$, were used for the study. Rats were obtained from the Central Animal House of Jamia Hamdard, New Delhi, India. They were housed in polypropylene cages in air-conditioned room and allowed free access to pellet diet and water ad libitum. The studies were carried out in accordance with the official regulations approved by the Animal Ethics Committee of Jamia Hamdard, New Delhi, India.

2.3. Experimental Protocol. The animals were divided into four groups $(n=6)$. The first group served as sham and saline was given orally. The second group was the ischemic group (MCAO: middle cerebral artery occluded) in which ischemia was induced for 2 hours followed by reperfusion for 22 hours. The third group was pre-treated with MK $\left(0.816 \mathrm{~g} \mathrm{~kg}^{-1}\right.$, orally for 15 days, single dose daily) followed by ischemia/reperfusion (MCAO + MK group). The fourth group was pre-treated with $\mathrm{MK}$ alone for 15 days as a drug control. After the last dose of MK was given on day 15, ischemia/reperfusion was induced on the same day. After reperfusion, the animals were assessed for neurobehavioral activities and then sacrificed.

2.4. Induction of Ischemia. The right middle cerebral artery occlusion was produced using an intraluminal filament model as earlier described by Longa et al. [11]. In brief, the rats were anesthetized with chloral hydrate $\left(400 \mathrm{mg} \mathrm{kg}^{-1}\right.$, intraperitoneally). A 4-0 nylon monofilament pre-coated with poly-L-lysine was inserted into the external carotid artery and advanced into the internal carotid artery. Two hours after the induction of ischemia, the filament was slowly withdrawn and animals were then returned to their cages for a period of 22 hours of reperfusion. In the shamoperated rats, the external carotid artery was surgically prepared for insertion of the filament but the filament was not inserted. The body temperature of animals was maintained with an infrared lamp and was continuously monitored for respiration and unresponsiveness throughout the surgical procedure. No animal mortality was observed during experimental procedures.

2.5. Behavioral Study. The behavioral tasks adopted in this study were designed to assess impairments consistent with the known functional architecture of the rat brain. The behavioral tests in each group were performed and the studies were carried out between 9:00 a.m. to 4:00 p.m. under standard laboratory conditions. All tests were performed and analyzed by subject blind to the experiment.

\subsection{Physical Performance Tests}

2.6.1. Rota-Rod (Motor Coordination). Omni rotor (Omnitech Electronics Inc., Columbus, OH, USA) was used to evaluate the motor in-coordination. It consisted of a rotating rod (75 $\mathrm{mm}$ diameter), which was divided into four compartments, permitting test of four rats at a time. The apparatus automatically recorded time $0.1 \mathrm{~s}$, when the rats fall off the rotating shaft. The speed was set at $10 \mathrm{rpm}$ and the cut-off time was $180 \mathrm{~s}$.

2.6.2. Open-Field Tests (Locomotor Activity). Open-field tests were done according to the method of Yamamoto et al. [12] with slight modification at ambient temperature ranging between 26 and $32^{\circ} \mathrm{C}$. The mean of session totals of vehicle and treatment groups were compared for locomotion (s), rest $(\mathrm{s})$, distance travelled $(\mathrm{cm})$, average speed $\left(\mathrm{cm} \mathrm{s}^{-1}\right)$. Videopath analyser (Coulbourn Instrument, Allentown, PA, USA) consists of an open-field chamber $(50 \times 50 \times 35 \mathrm{~cm})$, and a video camera was fixed over the chamber by an adjacent rod, an activity monitor, a programmer and a printer. The session total for all parameters was taken. Observations were recorded for $10 \mathrm{~min}$.

2.7. Tissue Preparation. After producing MCAO and assessment of behavioral parameters, the animals were sacrificed immediately and their brains were taken out to dissect the hippocampus (HIP). Post-mitochondrial supernatant (PMS) obtained from $10 \%$ homogenate of tissue was used for the estimation of various parameters related with oxidative stress.

\subsection{Biochemical Estimations}

2.8.1. Lipid Peroxidation (LPO). The procedure of Utley et al. [13] was used for the estimation of lipid peroxidation with some modifications. One milliliter of homogenate $(2.5 \%$ in chilled $\mathrm{KCl}$ ) was pipetted in a $20 \mathrm{ml}$ glass tube and incubated at $37 \pm 1^{\circ} \mathrm{C}$ in a metabolic shaker for 60 minutes. Similarly, 
TABle 1: Constituents of Majun Khadar (MK).

\begin{tabular}{|c|c|c|c|c|c|}
\hline S.N. & $\begin{array}{l}\text { Urdu/Arabic } \\
\text { name }\end{array}$ & English name & Origin & $\begin{array}{l}\text { Content } \\
(\mathrm{w} / \mathrm{kg})\end{array}$ & Clinical Importance \\
\hline (1) & Mastagi & Mastich & Plant/gum & $2 \mathrm{~g}$ & Stimulant, catarrh, astringent [10]. \\
\hline (2) & Boazyadan & $\begin{array}{l}\text { Sweet pelitory (Pyrethrum } \\
\text { indicum Linn) }\end{array}$ & Plant/leaves/seed/oil & $2 \mathrm{~g}$ & $\begin{array}{l}\text { Weakness of nerves, Arthritis, Gout, overall body } \\
\text { strengthener }\end{array}$ \\
\hline (3) & Shakakal & $\begin{array}{l}\text { Shekakul (Pustinaca } \\
\text { Secacut L) }\end{array}$ & Plant/Root & $2 \mathrm{~g}$ & Sexual debilities \\
\hline$(4)$ & Bheman & $\begin{array}{l}\text { Behen (Centaurea behen } \\
\text { Linn) }\end{array}$ & Plant/Root & $2 \mathrm{~g}$ & $\begin{array}{l}\text { Cardiotonic, relaxant, palpitation, delirium, sexual } \\
\text { debilities [10]. }\end{array}$ \\
\hline (5) & Gaozaban & $\begin{array}{l}\text { Borage (Borage Officinalis } \\
\text { Linn) }\end{array}$ & Plant/leaves/flowers & $2 \mathrm{~g}$ & $\begin{array}{l}\text { Cardiotonic, nervine tonic, palpitation, weakness of } \\
\text { brain, pneumonia, T.B, Infectious diseases [10]. }\end{array}$ \\
\hline (6) & Badranjboya & Mountain Balm & Plant/leaves & $2 \mathrm{~g}$ & $\begin{array}{l}\text { Strengthens heart, exhilarant, melancholia, nervine } \\
\text { tonic [10]. }\end{array}$ \\
\hline (7) & Sumbul-Teeb & $\begin{array}{l}\text { Valerian (Valeriana } \\
\text { Officinalis Linn) }\end{array}$ & Plant/Root & $2 \mathrm{~g}$ & $\begin{array}{l}\text { Antispasmodic, epilepsy, hysteria, bronchitis, loss of } \\
\text { appetite, liver disorders [10]. }\end{array}$ \\
\hline$(8)$ & Aushna & $\begin{array}{l}\text { Usnea (Usnea longissima } \\
\text { Linn) (Old man's beard) }\end{array}$ & Plant/leaves & $2 \mathrm{~g}$ & Cardiotonic, palpitation relaxant, delirium [10]. \\
\hline (9) & Qust-Shireen & Kartas root & Plant/Root & $2 \mathrm{~g}$ & Respiratory diseases, G.I.T disorders [10]. \\
\hline$(10)$ & Elaichi & Cardamom & Plant/Fruit & $2 \mathrm{~g}$ & $\begin{array}{l}\text { Vasodilator, Digestive, Diuretic, Cardiotonic, } \\
\text { Stimulant, carminative, anti-flatulent, cure for } \\
\text { obesity [10]. }\end{array}$ \\
\hline$(11)$ & $\begin{array}{l}\text { Barg- } \\
\text { Faranjamshak }\end{array}$ & Ram Tulsi (Sweet Basil) & Plant/Seed/leaves & $2 \mathrm{~g}$ & Cardiotonic G.I.T disorders [8]. \\
\hline$(12)$ & Saad-kofi & Sipertenius & Plant & $2 \mathrm{~g}$ & $\begin{array}{l}\text { Cardiotonic, nervine tonic, weakness of heart, } \\
\text { weakness of brain, G.I.T disorders, liver diseases [8]. }\end{array}$ \\
\hline$(13)$ & Uood-Saleeb & $\begin{array}{l}\text { Paeoni Root (Paeonia } \\
\text { officinalis) }\end{array}$ & Plant/Root & $3 \mathrm{~g}$ & Epilepsy, paralysis, facial paralysis, meningities [10] \\
\hline$(14)$ & Dalchini & $\begin{array}{l}\text { Cinnamon (Cinnamomum } \\
\text { verum) }\end{array}$ & Plant/Bark & $3 \mathrm{~g}$ & $\begin{array}{l}\text { Gastrointestinal, antibacterial, carminataive, } \\
\text { stimulant, Antiflatulant, cardiotonic, gastritis [10]. }\end{array}$ \\
\hline (I5) & Halhiya Kabuli & $\begin{array}{l}\text { Chebulic Myrobalan } \\
\text { (Terminalis chebula) }\end{array}$ & $\begin{array}{l}\text { Plant/Bark/leaves/ } \\
\text { Fruit }\end{array}$ & $4 \mathrm{~g}$ & $\begin{array}{l}\text { Nervine tonic, memory enhancer, stomach \& } \\
\text { intestine protectant, eye-sight enhancer, laxative, } \\
\text { blood purifier, cures bleeding, ulceration of gums } \\
{[10] \text {. }}\end{array}$ \\
\hline$(16)$ & $\begin{array}{l}\text { Takhm } \\
\text { Khaskhas } \\
\text { Safeed }\end{array}$ & $\begin{array}{l}\text { Poppy plant (Papaver } \\
\text { somniferum Linn) }\end{array}$ & Plant/Seed & $4 \mathrm{~g}$ & Analgesic, Protects digestive system [10] \\
\hline$(17)$ & Falfol daraz & $\begin{array}{l}\text { Long pepper (Piper longum } \\
\text { Linn) }\end{array}$ & Plant/Fruit & $7 \mathrm{~g}$ & $\begin{array}{l}\text { Nerve depressant, Cough, asthama, whooping cough } \\
\text { [10]. }\end{array}$ \\
\hline (18) & Falfal Siyah & $\begin{array}{l}\text { Black pepper (Piper nigrum } \\
\text { Linn) }\end{array}$ & Plant/Fruit & $7 \mathrm{~g}$ & $\begin{array}{l}\text { Digestive, expectorant, general body strengthener } \\
{[10] .}\end{array}$ \\
\hline (19) & Darong Akrabi & $\begin{array}{l}\text { Leopard's bane (Doronicum } \\
\text { hookarii Linn) }\end{array}$ & Plant/Root & $7 \mathrm{~g}$ & $\begin{array}{l}\text { General body strengthener, cardiotonic, delirium, } \\
\text { paralysis }[10] \text {. }\end{array}$ \\
\hline$(20)$ & Sajaz Hindi & Cinnamon Tamala & Plant/Roots/Wood & $7 \mathrm{~g}$ & $\begin{array}{l}\text { Cardiotonic, weakness of heart, hypertension, } \\
\text { weakness of brain, antispasmodic [10]. }\end{array}$ \\
\hline$(21)$ & Shahed & Honey & Animal & & Antibacterial, antibiotic \\
\hline$(22)$ & Pudina & Mint & Plant/Leaves & $7 \mathrm{~g}$ & Digestive, anti-emetic, Beauty packs [10] \\
\hline$(23)$ & Asaroon & $\begin{array}{l}\text { Asarum (Asarum } \\
\text { ewrospaeum Linn) }\end{array}$ & Plant/Root/Leaves & $7 \mathrm{~g}$ & Nervine tonic, paralysis [10]. \\
\hline$(24)$ & Shoranjan & $\begin{array}{l}\text { Colchicum (Colchicuni } \\
\text { autumale L.) }\end{array}$ & Plant/Bulbs & $4 \mathrm{~g}$ & Arthritis $[10]$. \\
\hline$(25)$ & Khoalnajan & $\begin{array}{l}\text { Galangal (Alpinia galangal } \\
\text { wild) }\end{array}$ & Plant/Roots & $2 \mathrm{~g}$ & $\begin{array}{l}\text { General body strengthner, Expectorant, Nervine } \\
\text { tonic }[10] \text {. }\end{array}$ \\
\hline$(26)$ & Zafran & Saffron & Plant/Flower & $1.5 \mathrm{~g}$ & Strengthner, antioxidant [10]. \\
\hline
\end{tabular}



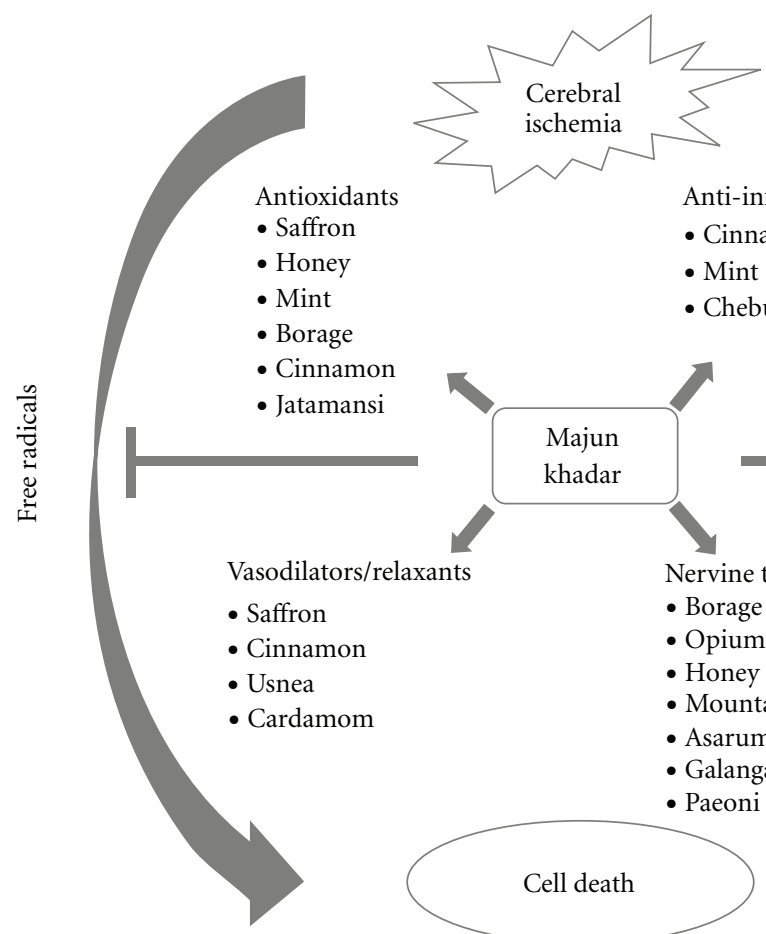

Anti-inflammatory

- Cinnamon

- Mint

- Chebulic myrobalan

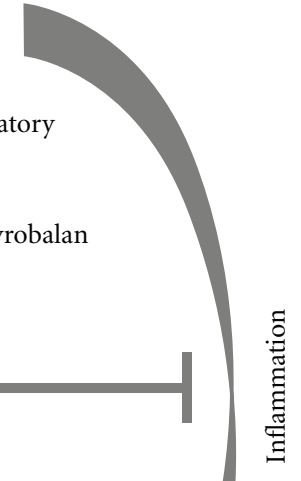

FIGURE 1: Hypothetical presentation of possible mechanisms of action of Majun Khadar (MK) against cerebral ischemia. Free radicals and inflammation are two major precipitators of ischemic cell death. Different constituents of MK have antioxidant and anti-inflammatory properties and many of them act as vasodilator, relaxant, nervine tonic and nerve stimulant which directly or indirectly prevent ischemic damage.

$1 \mathrm{ml}$ of the same homogenate was pipetted in a centrifuge tube and incubated at $0^{\circ} \mathrm{C}$. After 1 hour of incubation, $1.0 \mathrm{ml} 5 \%$ chilled tetrachloroacetic acid was added followed by $1.0 \mathrm{ml}$ of $0.67 \%$ TBA in each vial and proper mixing was done after each addition. The aliquot from each vial was transferred to a centrifuge tube and centrifuged at $2000 \times \mathrm{g}$ for 15 minutes. Thereafter, the supernatant was transferred to another tube and placed in the boiling water bath. After 10 minutes, the test tubes were cooled and the absorbance of each aliquot was measured at $535 \mathrm{~nm}$. The rate of lipid peroxidation was expressed as nanomoles of TBA reactive substance formed/hours/g of tissue using a molar extinction coefficient of $1.56 \times 10^{5}$ per M per $\mathrm{cm}$.

2.8.2. Glutathione (GSH). Reduced glutathione was determined by the method of Jollow et al. [14]. Postmitochondrial supernatant was precipitated with sulfosalicylic acid $(4.0 \%)$ in the ratio of $1: 1$. The samples were kept at $4^{\circ} \mathrm{C}$ for 1 hour and then centrifuged at $1200 \times \mathrm{g}$ for 15 minutes at $4^{\circ} \mathrm{C}$. The assay mixture contained supernatant, $0.1 \mathrm{M}$ phosphate buffer and DTNB (stock $=100 \mathrm{mM}$ in $0.1 \mathrm{M}$ phosphate buffer) in a total volume of $3 \mathrm{ml}$. The optical density of the reaction product was read at $\lambda 412 \mathrm{~nm}$ and results were expressed as nmol GSH/g tissue.

2.8.3. Estimation of Total Thiols (TT). The assay was done according to the method of Sedlak and Lindsay [15]. The assay mixture contained $0.2 \mathrm{ml}$ of homogenate $(10 \% \mathrm{w} / \mathrm{v})$,
$0.1 \mathrm{M}$ Tris-EDTA (pH 8.2) and $1.0 \mathrm{mM}$ DTNB in total volume of $2.7 \mathrm{ml}$ and mixed well. Thereafter, $8.3 \mathrm{ml}$ methanol was added and centrifuged at $3500 \times \mathrm{g}$ for 5 minutes. The yellow color developed was read immediately at $412 \mathrm{~nm}$ in a spectrophotometer (UV-1601, Shimadzu, Japan). The total thiol content was calculated by using a molar extinction coefficient of $13.6 \times 10^{3} \mathrm{M}^{-1} \mathrm{~cm}^{-1}$.

2.8.4. Glutathione Peroxidase (GPx). The activity of GPx was assayed according to the method described by Mohandas et al. [16]. The reaction mixture $(2 \mathrm{ml})$ consisted of a $1.44 \mathrm{ml}$ sodium-phosphate buffer ( $\mathrm{pH} 7.4), 0.1 \mathrm{ml}$ EDTA $(1 \mathrm{mM}), 0.1 \mathrm{ml}$ of $1 \mathrm{mM}$ sodium azide, $50 \mu \mathrm{l}$ glutathione reductase $\left(1 \mathrm{IU} \mathrm{ml}^{-1}\right), 0.1 \mathrm{ml}$ of $1 \mathrm{mM} \mathrm{GSH}, 0.1 \mathrm{ml} \mathrm{NADPH}$ $(0.2 \mathrm{mM}), 0.1 \mathrm{ml}$ of $10 \%$ PMS and $10 \mu \mathrm{l}$ of $0.25 \mathrm{mM}$ $\mathrm{H}_{2} \mathrm{O}_{2}$. The enzyme activity was calculated as nmol NADPH oxidized/minutes/mg protein, using a molar extinction coefficient of $6.22 \times 10^{3} \mathrm{M}^{-1} \mathrm{~cm}^{-1}$.

2.8.5. Glutathione S-Transferase (GST). The assay for the activity of GST was measured as described by Habig et al. [17]. For the assay of GST with CDNB as the substrate, the reaction mixture $(2 \mathrm{ml})$ consisted of a phosphate buffer (0.1 M, pH 7.4), $1 \mathrm{mM} \mathrm{GSH}, 10 \mathrm{mM} \mathrm{CDNB}$ and $10 \%$ postmitochondrial supernatant. An increase in optical density at $340 \mathrm{~nm}$ was recorded every $30 \mathrm{~s}$ for 3 minutes. The results were calculated by using the molar extinction co-efficient of $9.6 \times 10^{3} \mathrm{M}^{-1} \mathrm{~cm}^{-1}$ for CDNB conjugate at $340 \mathrm{~nm}$. The 


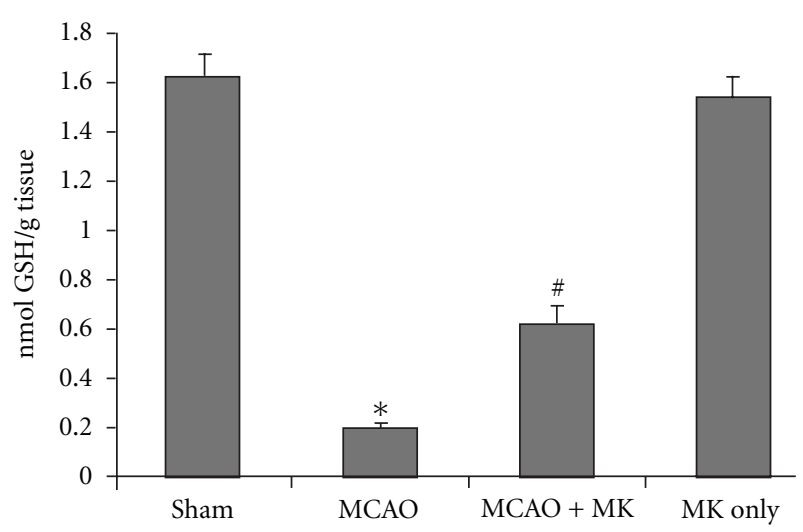

(a)

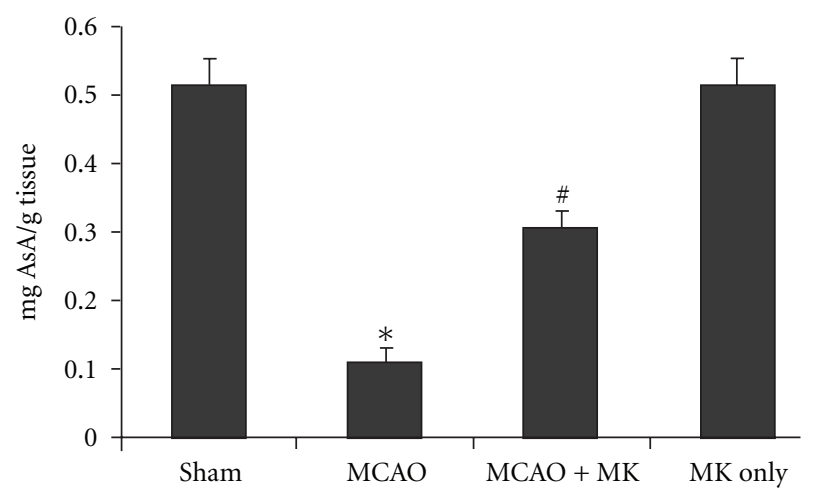

(b)

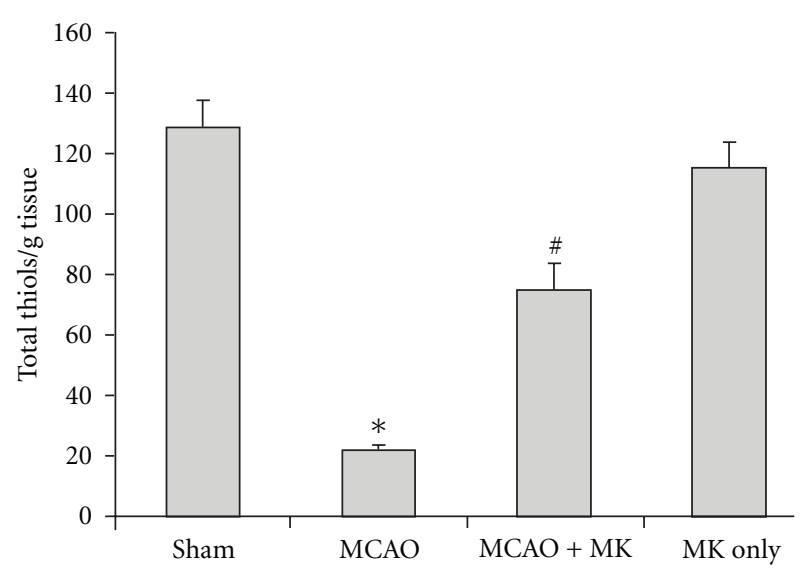

(c)

FIgURE 2: GSH content (a), ascorbic acid (b) and total thiols (c) in the hippocampus. Values are expressed as means $\pm \operatorname{SE}(n=6)$. Significance was determined as $* P<.001$ when compared with sham; ${ }^{\#} P<.01$ as compared with the MCAO group.

enzyme activity was expressed as nmol of CDNB conjugate formed/minutes/mg protein.

2.8.6. Glutathione Reductase (GR). The activity was measured by the method of Carlberg and Mannervick [18]. Briefly, the reaction mixture $(2 \mathrm{ml})$ consisted of $1.60 \mathrm{ml}$ of phosphate buffer $(0.1 \mathrm{mM}, \mathrm{pH} 7.4), 0.1 \mathrm{ml} \mathrm{NADPH}$ $(0.1 \mathrm{mM}), 0.1 \mathrm{ml}$ EDTA $(0.5 \mathrm{mM}), 0.1 \mathrm{ml}$ GSSG $(1 \mathrm{mM})$

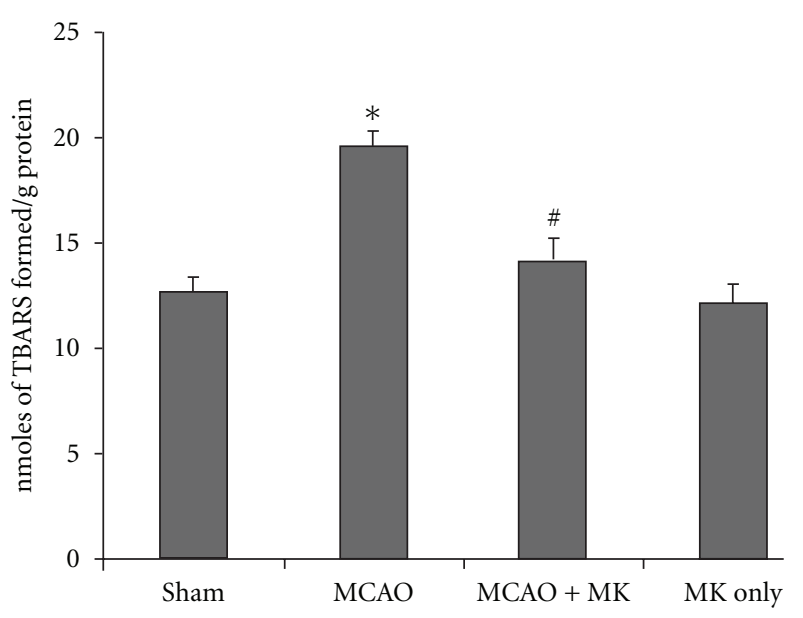

(a)

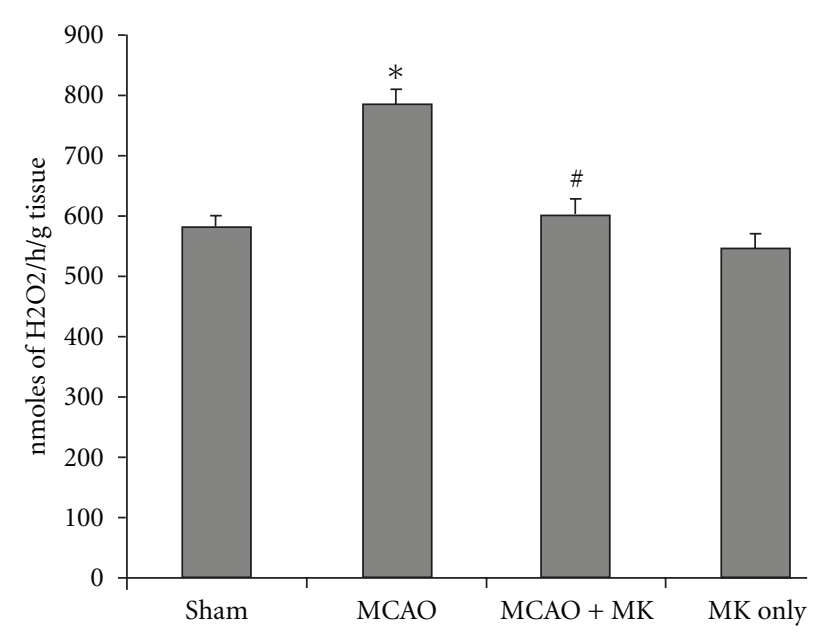

(b)

Figure 3: LPO level (a) and $\mathrm{H}_{2} \mathrm{O}_{2}$ content in different groups in hippocampus. Values are expressed as means SE $(n=6)$. Significant difference ${ }^{*} P<.001$ when compared with sham values; ${ }^{\#} P<.01$ when compared with the MCAO group.

and $0.1 \mathrm{ml}$ of post-mitochondrial supernatant (10\%). The reaction mixture was incubated at $30^{\circ} \mathrm{C}$ for 5 minutes before adding post-mitochondrial supernatant. The enzyme activity was determined by measuring the disappearance of $\mathrm{NADPH}$ at $340 \mathrm{~nm}$ using an extinction co-efficient $6.22 \times$ $10^{3} \mathrm{M}^{-1} \mathrm{~cm}^{-1}$. Specific activity of the enzyme was expressed as NADPH oxidized/minutes/mg protein.

2.8.7. Catalase (CAT). Catalase was estimated by the method of Claiborne et al. [19]. The assay mixture consisted of $1.95 \mathrm{ml}$ of $0.1 \mathrm{M}$ phosphate buffer ( $\mathrm{pH} 7.4$ ), $50 \mu \mathrm{l}$ of postmitochondrial supernatant $(10 \%)$. The reaction was initiated by adding $1.0 \mathrm{ml}$ of $0.019 \mathrm{M}$ hydrogen peroxide. A decrease in optical density at $240 \mathrm{~nm}$ was recorded after every $30 \mathrm{~s}$ for 3 minutes. The enzyme activity was calculated in terms of nmol $\mathrm{H}_{2} \mathrm{O}_{2}$ consumed/minutes/mg protein. 


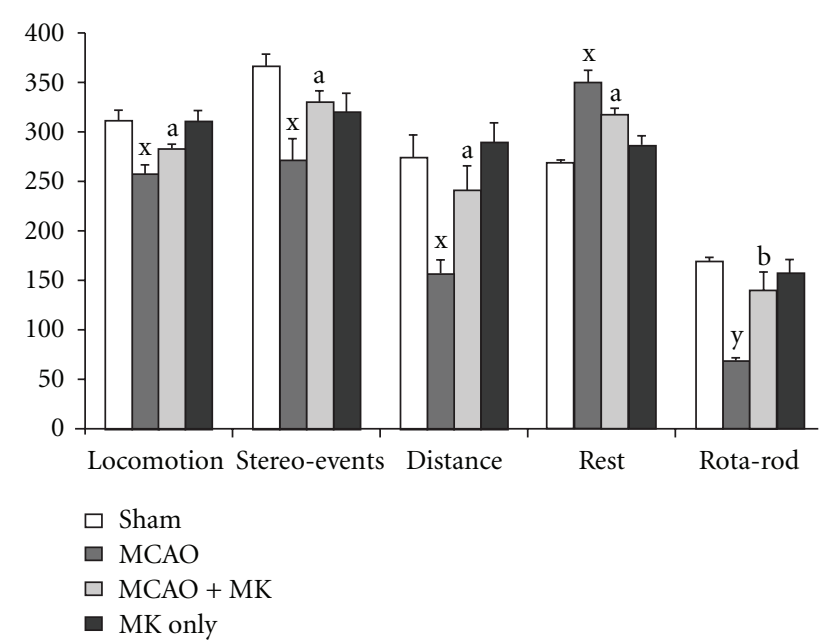

Figure 4: Neurobehavioral activities (locomotion, stereoevents, distance traveled, rest and rota-rod) in various groups. Significance was determined as ${ }^{\mathrm{x}} P<.01 ;{ }^{\mathrm{y}} P<.001$ when compared with sham values and ${ }^{\mathrm{a}} \mathrm{P}<.05$; $^{\mathrm{b}} \mathrm{P}<.01$ when compared with the MCAO group.

2.8.8. $\mathrm{Na}^{+} \mathrm{K}^{+}$ATPase. The activity of $\mathrm{Na}^{+} \mathrm{K}^{+}$-ATPase was determined as inorganic phosphorous (pi) release, using the method of Svoboda and Mossiger [20]. The $\mathrm{Na}^{+} \mathrm{K}^{+}$-ATPase activity was determined in two reaction media, $\mathrm{A}$ and $\mathrm{B}$. The reaction mixture A consisted of $0.2 \mathrm{M} \mathrm{KCl}, 1.0 \mathrm{M} \mathrm{NaCl}$, $0.1 \mathrm{M} \mathrm{MgCl}_{2}, 0.2 \mathrm{M}$ Tris- $\mathrm{HCl}$ buffer, $\mathrm{pH} 7.4$, and $0.1 \mathrm{ml}$ of brain homogenate $(10 \%)$ in a total volume of $2.0 \mathrm{ml}$. The reaction mixture $\mathrm{B}$ consisted of $0.1 \mathrm{M} \mathrm{MgCl}_{2}, 10 \mathrm{mM}$ ouabain, $1.0 \mathrm{M} \mathrm{NaCl}, 0.2 \mathrm{M}$ Tris- $\mathrm{HCl}$ buffer, $\mathrm{pH} 7.4$, and $0.1 \mathrm{ml}$ of brain homogenate $(10 \%)$ in a total volume of $2.0 \mathrm{ml}$. The enzyme reaction was started by adding $0.2 \mathrm{ml}$ of $25.0 \mathrm{mM}$ ATP at $37^{\circ} \mathrm{C}$ and terminated after 15 minutes by adding $1.0 \mathrm{ml}$ chilled $10 \%$ TCA. The mixture was centrifuged and the supernatant $(0.5 \mathrm{ml})$ was used for the estimation of inorganic phosphorous according to method of Fiske and Subborow [21].

2.8.9. Assay for Hydrogen Peroxide $\left(\mathrm{H}_{2} \mathrm{O}_{2}\right)$. Hydrogen peroxide was assayed by $\mathrm{H}_{2} \mathrm{O}_{2}$-mediated horse-radish peroxide (Hrp)-dependent oxidation of phenol red by the method of Pick and Keisari [22] with slight modification. $0.2 \mathrm{ml}$ microsomes were suspended in $1.0 \mathrm{ml}$ of solution containing $0.28 \mathrm{nM}$ phenol red, 8.5 units $\mathrm{Hrp}, 5.5 \mathrm{mM}$ dextrose and $0.05 \mathrm{M}$ phosphate buffer $(\mathrm{pH} 7.0)$ incubated at $37^{\circ} \mathrm{C}$ for 60 minutes. The reaction was stopped by the addition of $10 \mathrm{ml}$ of $\mathrm{NaOH}(10 \mathrm{~N})$, and then centrifuged at $800 \mathrm{~g}$ for 5 minutes. The absorbance of the supernatant was measured at $610 \mathrm{~nm}$ against reagent blank. The quantity of $\mathrm{H}_{2} \mathrm{O}_{2}$ produced, expressed as $n m o l H_{2} \mathrm{O}_{2} / \mathrm{h} / \mathrm{g}$ tissue based on the standard curve of 50-250 $\mathrm{nM} \mathrm{H}_{2} \mathrm{O}_{2}$-oxidized phenol red.

2.8.10. Ascorbic Acid (AsA). The ascorbic acid content was estimated by the method of Majhi et al. [23]. The reaction mixture consisted of $0.5 \mathrm{ml}$ of 2-4 dinitrophenyl hydrazine reagent (prepared in $1 \mathrm{M} \mathrm{HCl}$ ) and $0.1 \mathrm{ml}$ of supernatant obtained after precipitation with 20\% TCA. The mixture was
TABLE 2: Effect of cerebral ischemia on the activity of various enzymes in the hippocampus.

\begin{tabular}{lcccc}
\hline Enzymes & SHAM & MCAO & MCAO + MK & MK ONLY \\
\hline GP $\times$ & $16.30 \pm 0.93$ & $7.59 \pm 0.52^{\mathrm{a}}$ & $12.86 \pm 1.22^{\mathrm{x}}$ & $16.00 \pm 1.02$ \\
& & $(53.43 \%)$ & $(69.43 \%)$ & $(-1.84 \%)$ \\
GR & $34.54 \pm 1.50$ & $21.65 \pm 1.04^{\mathrm{a}}$ & $27.81 \pm 1.06^{\mathrm{x}}$ & $33.70 \pm 1.41$ \\
& & $(37.31 \%)$ & $(28.45 \%)$ & $(-2.43 \%)$ \\
$\mathrm{GST}$ & $16.29 \pm 0.72$ & $9.37 \pm 0.63^{\mathrm{a}}$ & $12.58 \pm 0.98^{\mathrm{y}}$ & $16.92 \pm 0.81$ \\
& & $(42.48 \%)$ & $(34.25 \%)$ & $(15.83 \%)$ \\
$\mathrm{CAT}$ & $6.38 \pm 0.33$ & $3.23 \pm 0.21^{\mathrm{a}}$ & $4.86 \pm 0.38^{\mathrm{y}}$ & $5.37 \pm 0.41$ \\
& & $(49.37 \%)$ & $(50.46 \%)$ & $(-15.83 \%)$ \\
$\mathrm{Na}^{+} \mathrm{K}^{+}$ & $4.52 \pm 0.25$ & $2.21 \pm 0.13^{\mathrm{a}}$ & $3.46 \pm 0.26^{\mathrm{x}}$ & $4.21 \pm 0.24$ \\
ATPase & & $(51.10 \%)$ & $(56.56 \%)$ & $(-6.8 \%)$ \\
\hline
\end{tabular}

Values are expressed as mean \pm S.E $(n=6)$ in nmoles/minutes/mg protein. Values in parentheses show the percentage increase or decrease with respect to their control. Significance was determined as ${ }^{\text {a }} P<.001$ sham versus MCAO. ${ }^{\mathrm{x}} P<.01 ;{ }^{\mathrm{y}} P<.05 \mathrm{MCAO}$ versus $\mathrm{MCAO}+\mathrm{MK}$.

incubated at $60^{\circ} \mathrm{C}$ for 1 hour. After cooling $2.5 \mathrm{ml}$ of $8.5 \%$ $\mathrm{H}_{2} \mathrm{SO}_{4}$ was added while the tubes were in ice. The absorbance was taken at $540 \mathrm{~nm}$ and the results were expressed as $\mathrm{mg}$ ASA/g tissue.

2.9. Statistical Analysis of Data. Data were analyzed for significance of difference using the Student's $t$-test. Values are expressed as means $\pm \mathrm{SE}(n=6)$. The significance of results was ascertained at $P<.05$.

\section{Results}

3.1. GSH, AsA and TT. A significant decrease $(P<.001)$ in the status of various endogenous cellular antioxidants, GSH, AsA and TT homeostasis was observed in the MCAO group when compared with the sham group (Figures 2(a), 2(b), and 2(c)). MK pre-treatment exhibited a significant restoration $(P<.01)$ in GSH, AsA and TT content in the MCAO + MK group when compared with the MCAO group (Figures 2(a), 2(b) and 2(c)). The MK sham group did not alter the status of GSH, AsA and TT as compared with sham values.

3.2. Antioxidant Enzymes and $\mathrm{Na}^{+} \mathrm{K}^{+}$ATPase. Activities of various antioxidant enzymes and $\mathrm{Na}^{+} \mathrm{K}^{+}$ATPase in the hippocampal region of different groups have been listed in Table 2. The activity of GPx, GR, GST, CAT and $\mathrm{Na}^{+} \mathrm{K}^{+}$ATPase was significantly depleted $(P<.001)$ in the $\mathrm{MCAO}$ group when compared with the sham group values. Whereas in the MCAO + MK group, MK pre-treatment showed a significant $(P<.05-.01)$ restoration in the level of various enzyme and $\mathrm{Na}^{+} \mathrm{K}^{+}$ATPase as compared with MCAO group. MK alone did not show any change in the status of any enzyme over control values.

3.3. LPO and $\mathrm{H}_{2} \mathrm{O}_{2}$ Content. The level of LPO and $\mathrm{H}_{2} \mathrm{O}_{2}$ content adds to the proof of the loss of scavengers and increased peroxidative damage during cerebral ischemia. A significant increase $(P<.001)$ in the content of LPO and 
$\mathrm{H}_{2} \mathrm{O}_{2}$ was observed in the MCAO group when compared with the sham group. In the MCAO + MK group, a significant decrease $(P<.01)$ was seen in the level of LPO and $\mathrm{H}_{2} \mathrm{O}_{2}$ when compared with the MCAO group (Figures 3(a) and $3(\mathrm{~b}))$. The MK sham group did not show any significant alterations in the status of TBARS and $\mathrm{H}_{2} \mathrm{O}_{2}$ when compared with the sham group.

3.4. Motor Coordination. Significant impairments were observed at the behavioral outcomes in the ischemic group. On the rota-rod task, a test that requires good coordination, balance and sensorimotor function, the MCAO group showed significant $(P<.001)$ impairments in coordination and balance as compared with the sham animals. Although they appeared to be motivated to run on the rod, rats with stroke could not keep up with the acceleration of the rod and fell approximately twice than control rat. But significant $(P<$ .05 ) improvement was observed in the MCAO + MK group in staying on the accelerating rod for a longer duration of time when compared with the MCAO group (Figure 4).

Open-field activity was related to ipsilateral cerebral hemisphere volume and the motor measurements. Openfield activities (locomotion, stereo events, distances traveled, average speed and rest) showed significant $(P<.01)$ deficits in the MCAO group when compared with the sham group. Whereas in the MCAO + MK group, the activities were reinstated significantly $(P<.05)$ when compared with the MCAO group (Figure 4).

\section{Discussion}

In this study, supplementation of MK for 15 days significantly boosted the neurobehavioral outcomes and neuronal defense mechanism against cerebral ischemia by increasing antioxidants activity related to lesion pathogenesis. The recuperation of the brain from oxidative stress during reperfusion after ischemia was preceded by recovery of GSH with its dependent enzymes and decreased oxidative damage. Restoration of the antioxidant homeostasis in the brain after reperfusion may have helped the brain recover from ischemic injury. Although MK is extensively used in Unani medicine, it lacks scientific grounds for its efficacy and to the best of our knowledge this is the first study to report its possible protective mechanisms against cerebral ischemic damage. One of the universally accepted etiologies of stroke is imbalance between factors of free radical formation and the maintenance of the neuronal integrity through the endogenous defense mechanism. In the present study, the major cellular defenses (both enzymatic and non enzymatic) were severely altered in the ischemic group as compared with the sham group, which was due to the increased formation of reactive oxygen species (ROS) and dwindling levels of the radical scavengers. However, this imbalance was prevented by MK supplementation. A substantial elevation in the LPO level and $\mathrm{H}_{2} \mathrm{O}_{2}$ content along with the depletion in the activity of various protective antioxidant enzymes in the ischemic brains which has been validated with immense earlier reports was observed [3, 4, 24, 25]. However, pretreatment with MK resulted in the reversal of the increased LPO level, $\mathrm{H}_{2} \mathrm{O}_{2}$ content and up-regulated the depleted antioxidant enzymes when compared with the ischemic group suggesting the decreased formation of ROS or radical scavenging activity of MK after ischemic injury. Neuronal and cognitive impairments were seen to be improved after stroke with decoction of herbs (Gagamjungjihwan) and (Frustus Euodiae) and the Chinese herbal formula (FBD) by the restoration of GSH content and lowering the lipid peroxides during ischemic damage $[26,27]$.

Diminished supply of oxygen and energy to the brain leads toward the first step of oxidative damage. A drug having vasodilatory action may be the answer for this problem that might increase the oxygen and energy supply. The neuroprotection offered by MK may be due to the additive effect of the principle components, for example, saffron, honey, Nardostachys jatamansi, cardamom, mint, cinnamon, black pepper, mastich and usnea. Saffron and its active component, crocetin has antioxidant potential $[28,29]$, lipid lowering and vasodilatory properties which leads to increased blood flow thereby supplying oxygen and nutrient to the ischemic penumbra [30]. Honey is a well-known antioxidant, anti-microbial, wound healing and nutritive agent with its final stamp for accreditation from US Medical Archives. The presence of various polyphenolic compounds, pinocembrin, pinobanksin, chrysin, galagin, ascorbic acid, enzymes (glucose oxidase, catalase and peroxidases) attribute to its antioxidant potential $[31,32]$. In the present study, increased activity of antioxidant enzymes and less peroxidative damage to the brain can be attributed to the presence of honey in MK. MK also contains Nardostachys jatamansi which has the potential to scavenge superoxide radicals, hydroxyl radicals and singlet oxygen $[33,34]$ due to which it was able to offer protection during cerebral ischemic damage. Malva et al. [35] indicated its neuroprotective property against signaling pathways involving $\left(\mathrm{Ca}^{2+}\right)_{i}$ and the redox state of the cells, which can play its role in ischemic damage. The mechanism by which Nardostachys jatamansi exerts its effect is not clearly known but it enhances the function of gamma amino butyric acid (GABA) [36-38] and GABA potentiates the treatment of ischemic stroke [39] because there are increased concentrations of excitatory amino acids. These properties of Nardostachys jatamansi potentiates the antioxidant and neuroprotective potential of MK against cerebral ischemic damage. The presence of mint another important constituent in MK adds to the anti-inflammatory, antioxidant and/or radical scavenging properties [40-43]. The presence of carveol, an active organic constituent of mint, and transition elements (e.g., $\mathrm{Mn}, \mathrm{Zn}$ and $\mathrm{Co}$ ) is responsible for the free radical scavenging activity of the mint [44]. All these properties might have synergistically led to decreased ischemic damage after MK pre-treatment.

Variant behavioral tasks were employed in the present study to detect motor and sensorimotor dysfunction in rats after cerebral ischemia. We observed significant alterations in the motor, locomotion, rest time and stereo events in the ischemic group when compared with the sham group. But in the MK pre-treated group, a positive restoration 
in the mentioned behavioral events was observed when compared with its respective controls. This amelioration in behavior may be attributed to the protection offered by its various pharmacologically important constituents of MK such as Nardostachys jatamansi, cinnamon, saffron and mint. It might be due to antioxidant potential of Nardostachys jatamansi that may have helped to restore the antioxidant levels which play an important role in improving the behavior. Various reports suggest the improvement in behavioral outputs offered by Nardostachys jatamansi [45, 46]; our data are in agreement with these previous reports. The vasodilatory activity of carotenoids present in saffron, antioxidant potential of mint and brain-boosting function of cinnamon that enhance cognition, working memory, visual-motor speed added to the effectiveness of MK against cerebral ischemia-induced behavioral dysfunctions [47]. The collective properties of various constituents of MK such as increasing blood flow, oxygen content, radical scavenging and brain boosting actions may have restored the damaged regions of the brain and thereby improving the behavioral outcomes. Again a Chinese herbal medicine, Tokishakuyakusan, reported to suppress impairments of lower limbs and influencing visuospatial perception for post-stroke patients [48].

Exploring the intricate protection offered by MK may bring healthy, safe, natural, multimodal protective properties of these various plant extracts which can help to protect the brain from ischemic damage. In conclusion, MK has anti-ischemic properties and it protects brain from cerebral ischemia-induced oxidative damage due to the additive effect of its various pharmacologically important constituents that possess antioxidant, ROS scavenging and vasodilatory properties. Apart from the above-mentioned efficacies, it would be very interesting to explore specifically any possible neuro-nutrient role of $\mathrm{MK}$ in neurological disorders as it has seven constituents that are nerve boosters.

\section{Funding}

Central Council for Research in Unani Medicine (CCRUM), Govt of India, New Delhi.

\section{Acknowledgment}

S. Yousuf is thankful to Mr Badar, librarian, Faculty of Unani Medicines, Jamia Hamdard, for providing literature and their translation in English.

\section{References}

[1] J. D. Koch, D. K. Miles, J. A. Gilley, C. P. Yang, and S. G. Kernie, "Brief exposure to hyperoxia depletes the glial progenitor pool and impairs functional recovery after hypoxic-ischemic brain injury," Journal of Cerebral Blood Flow \& Metabolism, vol. 28, pp. 1294-1306, 2008.

[2] N. R. Farnsworth, "The role of ethnopharmacology in drug development," in Bioactive Compounds from Plants', (Ciba Foundation Symposium, Chicago, Illinois), pp. 2-21, Wiley, Chichester, UK, 1990.
[3] S. Yousuf, S. Salim, M. Ahmad, A. S. Ahmed, M. A. Ansari, and F. Islam, "Protective effect of Khamira Abresham Uood Mastagiwala against free radical induced damage in focal cerebral ischemia," Journal of Ethnopharmacology, vol. 99, no. 2, pp. 179-184, 2005.

[4] S. Yousuf, F. Atif, M. Ahmad et al., "Selenium plays a modulatory role against cerebral ischemia-induced neuronal damage in rat hippocampus," Brain Research, vol. 1147, no. 1, pp. 218-225, 2007.

[5] S. Saleem, M. Ahmad, K. S. Zafar, A. S. Ahmad, and F. Islam, "Protective effect of Nardostachys jatamansi in rat cerebral ischemia," Pharmacology Biochemistry and Behavior, vol. 74, pp. 481-486, 2003.

[6] S. Saleem, M. Ahmad, A. S. Ahmad et al., "Effect of saffron (Crocus sativus) on neurobehavioral and neurochemical changes in cerebral ischemia in rats," Journal of Medicinal Food, vol. 9, no. 2, pp. 246-253, 2006.

[7] S. Ahmad, S. Yousuf, T. Ishrat et al., "Effect of dietary sesame oil as antioxidant on brain hippocampus of rat in focal cerebral ischemia," Life Sciences, vol. 79, no. 20, pp. 1921-1928, 2006.

[8] U. Kabeer, Bayaaz-e-Kabeer: Part II, Daftarul Miyah, Billimaran, New Delhi, India, 15th edition, 1951.

[9] H. Panda, Handbook on Ayurvedic Medicines with Formulae, Processes and Their Uses, National Institute of Industrial Research, New Delhi, India, 2002.

[10] H. Sifiuddin, Unani Adviya Mafarruda, Tariki Urdu Bureau, New Delhi, India, VIII edition, 1999.

[11] E. Z. Longa, P. R. Weinstein, S. Carlson, and R. Cummins, "Reversible middle cerebral artery occlusion without craniectomy in rats," Stroke, vol. 20, no. 1, pp. 84-91, 1989.

[12] M. Yamamoto, A. Tamura, T. Kirino, M. Shimizu, and K. Sano, "Behavioral changes after focal cerebral ischemia by left middle cerebral artery occlusion in rats," Brain Research, vol. 452, pp. 323-328, 1998.

[13] C. Utley, F. Bernhein, and P. Hochslein, "Effects of sulfhydryl reagent on peroxidation in microsomes," Archives of Biochemistry and Biophysics, vol. 260, pp. 21-31, 1967.

[14] D. J. Jollow, J. R. Mitchell, N. Zampaghone, and J. R. Gillete, "Bromobenzene induced liver necrosis: protective role of glutathione and evidence for 3,4-bromobenzene oxide as the hepatotoxic intermediate," Pharmacology, vol. 11, pp. 161169, 1974.

[15] J. Sedlak and R. H. Lindsay, "Estimation of total, proteinbound, and nonprotein sulfhydryl groups in tissue with Ellman's reagent," Analytical Biochemistry, vol. 25, pp. 192205, 1968.

[16] J. Mohandas, J. J. Marshall, G. G. Duggin, J. S. Horvath, and D. Tiller, "Differential distribution of glutathione and glutathione related enzymes in rabbit kidneys: possible implication in analgesic neuropathy," Cancer Research, vol. 44, pp. 5086-5091, 1984.

[17] W. H. Habig, M. J. Pabst, and W. B. Jokoby, "GlutathioneS-transferase: the first enzymatic step in mercapturic acid formation," The Journal of Biological Chemistry, vol. 249, pp. 7130-7139, 1974.

[18] I. Carlberg and B. Mannervik, "Purification and characterization of the flavoenzyme glutathione reductase from rat liver," Journal of Biological Chemistry, vol. 250, no. 14, pp. 54755480, 1975.

[19] A. Caliborne, "Catalase activity" in CRC Hand Book of Methods for Oxygen Radical Research, G. Wakd, Ed., pp. 283294, CRC Press, Boca Raton, Fla, USA, 1985. 
[20] P. Svoboda and B. Mosinger, "Catecholamines and the brain microsomal $\mathrm{Na}, \mathrm{K}$-adenosinetriphosphatase. I. Protection against lipoperoxidative damage," Biochemical Pharmacology, vol. 30, no. 5, pp. 427-432, 1981.

[21] C. H. Fiske and Y. Subborow, "The calorimetric determination of phosphorous," The Journal of Biological Chemistry, vol. 66, pp. 375-400, 1925.

[22] A. Pick and Y. Kesari, "Superoxide anion and $\mathrm{H}_{2} \mathrm{O}_{2}$ production by chemically elicited peritoneal macrophages-induction by multiple non-phagocytic stimulus," Cellular Immunology, vol. 59, pp. 301-308, 1981.

[23] S. Majhi, B. S. Jena, and B. K. Patnaik, "Effect of age on lipid peroxides, lipofuscin and ascorbic acid contents of the lungs of male garden lizard," Comparative Biochemistry and Physiology C, vol. 126, no. 3, pp. 293-298, 2000.

[24] S. Love, "Oxidative stress in brain ischemia," Brain Pathology, vol. 9, no. 1, pp. 119-131, 1999.

[25] E. Ozerol, S. Bilgic, M. Iraz, A. Cigli, A. Ilhan, and O. Akyol, "The protective effect of erdosteine on short-term global brain ischemia/reperfusion injury in rats," Progress in NeuroPsychopharmacology and Biological Psychiatry, vol. 33, pp. 20 24, 2009.

[26] Z. Lin, D. Zhu, Y. Yan et al., "An antioxidant phytotherapy to rescue neuronal oxidative stress," Evidence-Based Complementary and Alternative Medicine, 2009.

[27] B. Lee, E. J. Choi, E. J. Lee et al., "The neuroprotective effect of methanol extract of gagamjungjihwan and fructus euodiae on ischemia-induced neuronal and cognitive impairment in the rat," Evidence-Based Complementary and Alternative Medicine, 2009.

[28] S. C. Nair, M. J. Salomi, C. D. Varghese, B. Pannikar, and K. R. Pannikar, "Effect of saffron on thymocyte proliferation, intracellular gluthathione levels and its antitumor activity," BioFactors, vol. 4, pp. 51-54, 1992.

[29] F. I. Abdullaev and E. Gonzalez De Mejia, "Inhibition of colony formation of Hela cells by naturally occurring and synthetic agents," BioFactors, vol. 5, no. 3, pp. 133-138, 1995.

[30] Y. Deng, Z.-G. Guo, Z.-L. Zeng, and Z. Wang, "Studies on the pharmacological effects of saffron(Crocus sativus L.) - a review," Zhongguo Zhongyao Zazhi, vol. 27, no. 8, pp. 567-568, 2002.

[31] R. Jones, "Honey and healing through the ages," Journal of ApiProduct and ApiMedical Science, vol. 1, pp. 2-5, 2009.

[32] J. P. Kelly, D. W. Kaufman, K. Kelley, L. Rosenberg, T. E. Anderson, and A. A. Mitchell, "Recent trends in use of herbal and other natural products," Archives of Internal Medicine, vol. 165, no. 3, pp. 281-286, 2005.

[33] A. J. Hunter, K. B. Mackay, and D. C. Rogers, “To what extent have functional studies of ischaemia in animals been useful in the assessment of potential neuroprotective agents," Trends in Pharmacological Sciences, vol. 19, pp. 59-66, 1998.

[34] Y. B. Tripathi, E. Tripathi, and A. Upadhyay, "Antilipid peroxidative property of Nardostachys jatamanasi," Indian Journal of Experimental Biology, vol. 34, no. 11, pp. 1150-1151, 1996.

[35] J. O. Malva, S. Santos, and T. Macedo, "Neuroprotective properties of Valeriana officinalis extracts," Neurotoxicity Research, vol. 6, no. 2, pp. 131-140, 2004.

[36] K. A. Hamied, V. M. Bakshi, and L. P. Aghara, "Pharmacological investigation of Nardostachys jatamansi root," Journal of Scientific \& Industrial Research, vol. 21, pp. 100-103, 1962.

[37] V. M. Prabhu, K. S. Karanth, A. Rao, P. M. Vidya, and K. Sudhakar, "Effect of Nardostachys jatamansi on biogenic amines and inhibitory amino acids in the rat brain," Planta Medica, vol. 60, pp. 114-117, 1994.

[38] P. J. Houghton, "The scientific basis for the reputed activity of valerian," Journal of Pharmacy and Pharmacology, vol. 51, no. 5, pp. 505-512, 1999.

[39] A. R. Green, A. H. Hainsworth, and D. M. Jackson, "GABA potentiation: a logical pharmacological approach for the treatment of acute ischaemic stroke," Neuropharmacology, vol. 39, no. 9, pp. 1483-1494, 2000.

[40] F. Conforti, S. Sosa, M. Marrelli et al., "In vivo antiinflammatory and in vitro antioxidant activities of Mediterranean dietary plants," Journal of Ethnopharmacology, vol. 116, no. 1, pp. 144-151, 2008.

[41] H. J. D. Dorman, M. Koşar, K. Kahlos, Y. Holm, and R. Hiltunen, "Antioxidant properties and composition of aqueous extracts from Mentha species, hybrids, varieties, and cultivars," Journal of Agricultural and Food Chemistry, vol. 51, no. 16, pp. 4563-4569, 2003.

[42] N. Mimica-Dukić, B. Božin, M. Soković, B. Mihajlović, and M. Matavulj, "Antimicrobial and antioxidant activities of three Mentha species essential oils," Planta Medica, vol. 69, no. 5, pp. 413-419, 2003.

[43] R. P. Choudhury, A. Kumar, and A. N. Garg, "Analysis of Indian mint (Mentha spicata) for essential, trace and toxic elements and its antioxidant behaviour," Journal of Pharmaceutical and Biomedical Analysis, vol. 41, no. 3, pp. 825-832, 2006.

[44] F. Khallouki, B. Speigelhalder, H. Bart, and R. W. Owen, "Secondary metabolites of the Argan tree (Morocco) may have disease prevention properties," African Journal of Biotechnology, vol. 4, pp. 381-388, 2005.

[45] K. Fukui, N.-O. Omoi, T. Hayasaka et al., "Cognitive impairment of rats caused by oxidative stress and aging, and its prevention by vitamin E," Annals of the New York Academy of Sciences, vol. 959, pp. 275-284, 2002.

[46] K. Fukui, K. Onodera, T. Shinkai, S. Suzuki, and S. Urano, "Impairment of learning and memory in rats caused by oxidative stress and aging, and changes in antioxidative defense systems," Annals of the New York Academy of Sciences, vol. 928, pp. 168-175, 2001.

[47] I. Runnie, M. N. Salleh, S. Mohamed, R. J. Head, and M. Y. Abeywardena, "Vasorelaxation induced by common edible tropical plant extracts in isolated rat aorta and mesenteric vascular bed," Journal of Ethnopharmacology, vol. 92, no. 2-3, pp. 311-316, 2004.

[48] H. Goto, N. Satoh, Y. Hayashi et al., "A Chinese herbal medicine, tokishakuyakusan, reduces the worsening of impairments and independence after stroke: a 1-year randomized, controlled trial," Evidence-Based Complementary and Alternative Medicine, 2009. 


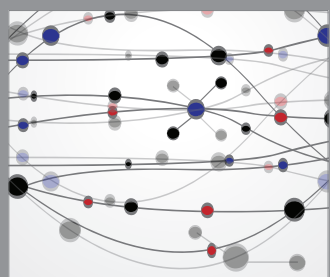

The Scientific World Journal
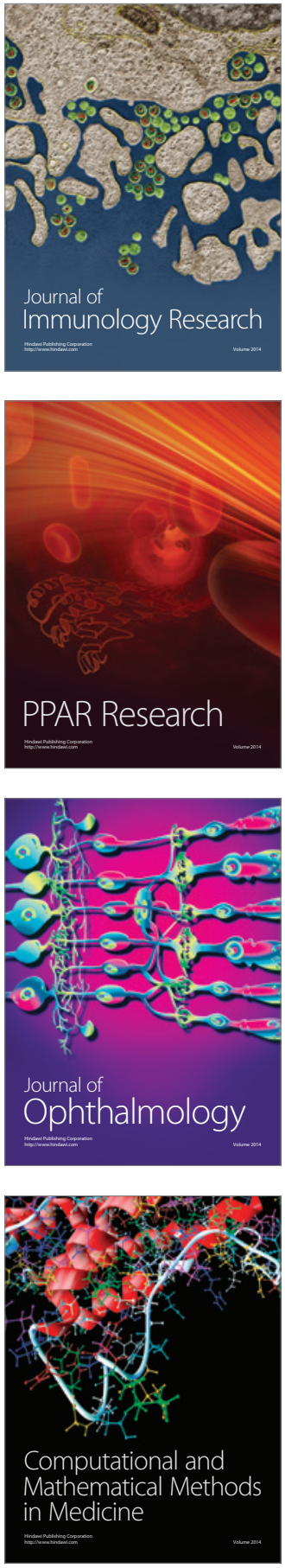

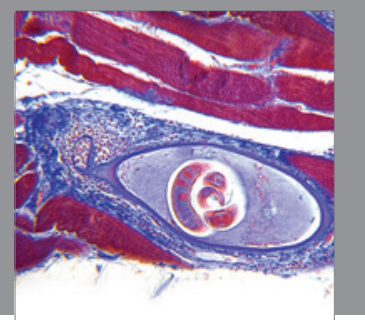

Gastroenterology

Research and Practice
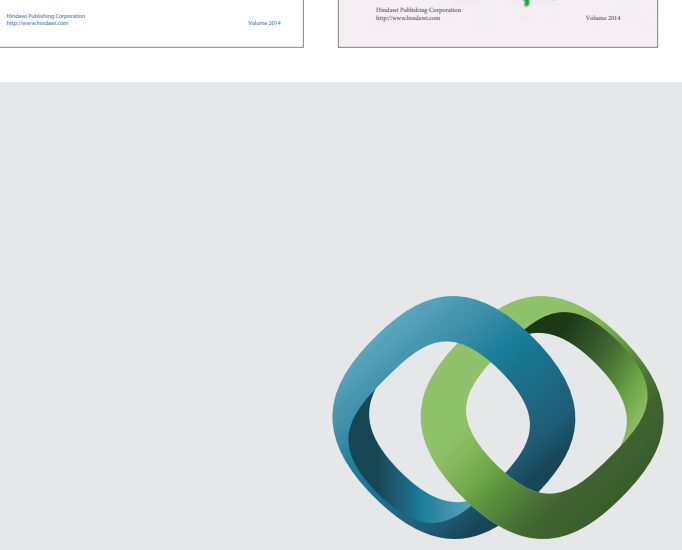

\section{Hindawi}

Submit your manuscripts at

http://www.hindawi.com
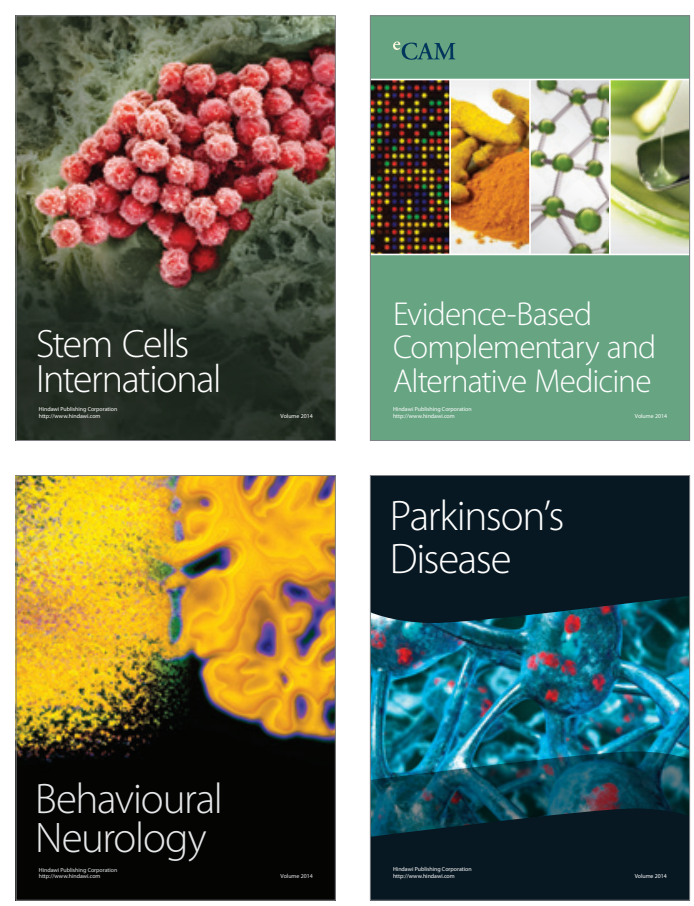

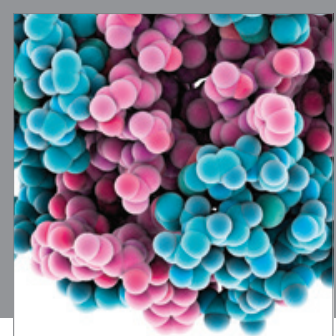

Journal of
Diabetes Research

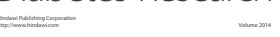

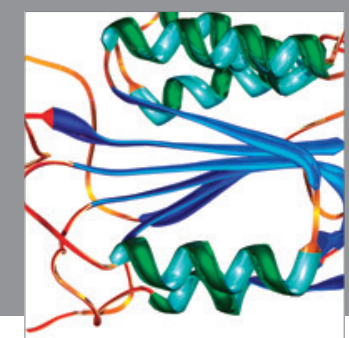

Disease Markers
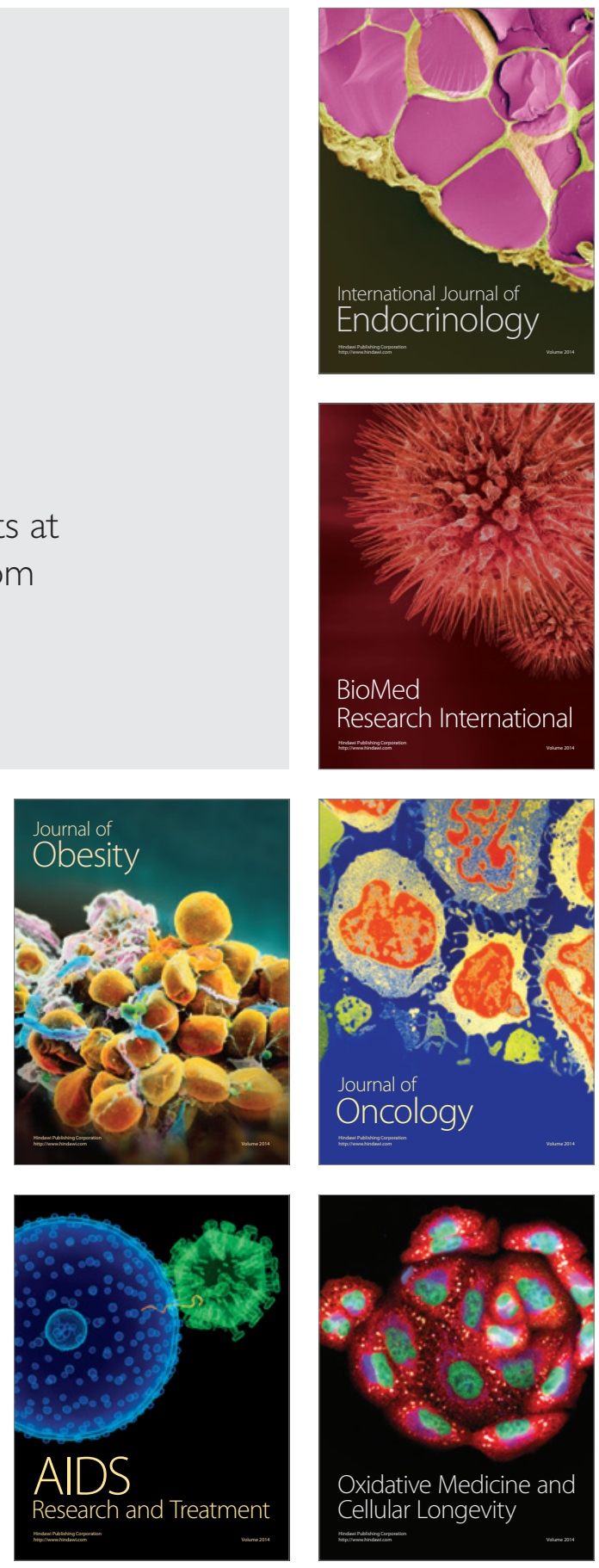